\title{
Anthelmintic activity of Eucalyptus citriodora essential oil and its major component, citronellal, on sheep gastrointestinal nematodes
}

Atividade anti-helmíntica do óleo essencial de Eucalyptus citriodora e seu componente majoritário, citronelal, sobre nematoides gastrintestinais de ovinos

José Vilemar de Araújo-Filho'; Wesley Lyeverton Correia Ribeiro²; Weibson Paz Pinheiro André1;

Géssica Soares Cavalcante ${ }^{3}$; Thays Tabosa Rios ${ }^{1}$; Gabriela Maria Schwinden ${ }^{1}$; Letícia Oliveira da Rocha ${ }^{4}$;

Iara Tersia Freitas Macedo ${ }^{1}$; Selene Maia de Morais ${ }^{3}$; Claudia Maria Leal Bevilaqua ${ }^{1}$;

Lorena Mayana Beserra de Oliveira ${ }^{1 *}$

\begin{abstract}
${ }^{1}$ Laboratório de Doenças Parasitárias, Programa de Pós-graduação em Ciências Veterinárias, Faculdade de Veterinária, Universidade Estadual do Ceará - UECE, Fortaleza, CE, Brasil

${ }^{2}$ Departamento de Fisiologia e Farmacologia, Faculdade de Medicina, Universidade Federal do Ceará - UFC, Fortaleza, CE, Brasil

${ }^{3}$ Laboratório de Química de Produtos Naturais, Programa de Pós-graduaçáo em Ciências Veterinárias, Faculdade de Veterinária, Universidade Estadual do Ceará - UECE, Fortaleza, CE, Brasil

${ }^{4}$ Laboratório de Biologia Celular e Tecidual, Centro de Biociências e Biotecnologia, Universidade Estadual do Norte Fluminense Darcy Ribeiro, Campos dos Goytacazes, RJ, Brasil
\end{abstract}

Received May 29, 2019

Accepted September 13, 2019

\begin{abstract}
This study aimed to evaluate the anthelmintic activity of Eucalyptus citriodora essential oil and citronellal on sheep gastrointestinal nematodes. Essential oil composition was determined by gas chromatography mass spectrometry. The substances were evaluated in vitro using adult worm motility test (AWMT) and transmission electron microscopy (TEM). The acute toxicity test in mice and the fecal egg count reduction test (FECRT) in sheep were performed. Citronellal was confirmed as the essential oil major constituent (63.9\%). According to the AWMT, $2 \mathrm{mg} / \mathrm{mL}$ of essential oil and citronellal completely inhibited Haemonchus contortus motility at $6 \mathrm{~h}$ post exposure. H. contortus exposed to essential oil and citronellal exhibited internal ultrastructural modifications. The lethal dose 50 values in mice were 5,000 and 2,609 mg/kg for essential oil and citronellal, respectively. E. citriodora essential oil reduced sheep epg at 14 days post treatment by $69.5 \%(P<0.05)$. No significant differences were observed in epg between the citronellal and negative control groups $(P>0.05)$. The interaction between citronellal and other constituents in the essential oil may be relevant for its in vivo anthelmintic activity. Thus, E. citriodora essential oil and citronellal pharmacokinetic studies may help elucidate the anthelmintic activity of these compounds.
\end{abstract}

Keywords: Haemonchus contortus, Phytotherapy, alternative control, monoterpenoid.

\section{Resumo}

Este trabalho objetivou avaliar a atividade anti-helmíntica do óleo essencial de Eucalyptus citriodora e citronelal sobre nematoides gastrintestinais de ovinos. A composição do óleo essencial foi determinada por cromatografia gasosa acoplada à espectrometria de massas. As substâncias foram avaliadas in vitro utilizando-se teste de motilidade de vermes adultos (AWMT) e microscopia eletrônica de transmissão (TEM). Teste de toxicidade aguda em camundongos e teste de reduçáo da contagem de ovos fecais (FECRT) em ovinos foram realizados. Citronelal foi confirmado como componente majoritário do óleo essencial (63,9\%). No AWMT, $2 \mathrm{mg} / \mathrm{mL}$ de óleo essencial e citronelal inibiram completamente a motilidade de $H$. contortus 6 h pós-exposição. H. contortus expostos ao óleo essencial e citronelal exibiram modificaçóes ultraestruturais internas. Os valores da dose letal 50 em camundongos foram 5.000 e $2.609 \mathrm{mg} / \mathrm{kg}$ para óleo essencial 
e citronelal, respectivamente. Óleo essencial de E. citriodora reduziu opg de ovinos 14 dias pós-tratamento em 69,5\% $(P<0,05)$. Não houve diferença significativa de opg entre grupo controle negativo e citronelal $(P>0,05)$. A interação entre citronelal e outros constituintes do óleo essencial pode ser relevante na atividade anti-helmíntica in vivo. Portanto, avaliação farmacocinética do óleo essencial de E. citriodora e citronelal pode auxiliar a elucidar a atividade anti-helmíntica desses compostos.

Palavras-chave: Haemonchus contortus, fitoterapia, controle alternativo, monoterpenoide.

\section{Introduction}

Gastrointestinal nematodes are considered one of the greatest threats to goat and sheep farming, causing reduced weight gain, diarrhea, anemia and, in severe cases, death. Haemonchus contortus is a parasite that is highly prevalent in Brazilian herds and pathogenic due to its hematophagous feeding habit (FERREIRA et al., 2013; ASHRAF \& PRICHARD, 2014).

The control of small ruminant helminthiasis is almost exclusively realized with synthetic anthelmintics. However, reports of resistant nematode populations are becoming more common all over the world. Low efficacy was reported even for monepantel and derquantel plus abamectin, the two anthelmintic most recently launched on the market. Thus, anthelmintic resistance is currently considered one of the main challenges for goat and sheep parasite control (KOTZE \& PRICHARD, 2016; SALES \& LOVE, 2016).

The search for alternative control methods is essential, and studies have been carried out for this purpose. Many of these studies have demonstrated the potential promising of the phytotherapy. Thus, plant extracts, decoctions, essential oils and isolated bioactive compounds have been widely evaluated for their anthelmintic activity (KEARNEY et al., 2016; ANDRÉ et al., 2016; RIBEIRO et al., 2017).

Essential oils are complex mixtures of volatile secondary metabolites produced by aromatic plants and often obtained by hydrodistillation. Although essential oils can contain a high range of constituents, two or three are present in greater quantity. Generally, the major constituent or the synergic interaction between constituents determines the biological properties of the essential oils (BAKKALI et al., 2008; BALLHORN et al., 2009; BENELLI \& PAVELA, 2018).

The genus Eucalyptus belongs to the family Myrtaceae, which comprises approximately 900 species and subspecies. In addition to exploitation of its wood, Eucalyptus spp. is well known for its essential oils, widely marketed and used in the fragrance and pharmaceutical industries (BATISH et al., 2008). The essential oil of E. citriodora (Lemon Scented Eucalyptus) is one of the most popular in Brazil, together with E. staigeriana and E. globulus essential oils. The main constituent of E. citriodora essential oil is a monoterpenoid, citronellal (60-80\%) (VITTI \& BRITO, 2003; HASEGAWA et al., 2008).

E. citriodora essential oil has been reported to possess different biological activities, such as antibacterial and antifungal (BRITO et al., 2012; ELAISSI et al., 2012), anti-inflammatory, analgesic (GBENOU et al., 2013) and insecticidal (MACIEL et al., 2010). Citronellal demonstrated antifungal activity (NAKAHARA et al., 2003) and effect on insects (KIM et al., 2005).
E. citriodora essential oil (71.77\% citronellal) was evaluated in vitro against $H$. contortus. This oil showed an efficacy of $98.8 \%$ on egg hatching inhibition and $99.71 \%$ on larval development inhibition at 5.3 and $10.6 \mathrm{mg} / \mathrm{mL}$, respectively. The same oil was evaluated in goats using the fecal egg count reduction test (FECRT). The animals received $500 \mathrm{mg} / \mathrm{kg}$ for three consecutive days, and after 15 days, there was a $60.3 \%$ reduction in the egg count (MACEDO et al., 2011).

The in vitro effects of $E$. citriodora essential oil and its main constituent, citronellal, on $H$. contortus eggs, larvae and adult motility have been evaluated; both synthetic anthelmintic-susceptible and resistant $H$. contortus isolates were tested. Both products showed effectiveness against all life stages of the tested isolates, and it was suggested that citronellal was mainly responsible for the anthelmintic efficacy of the essential oil. However, no data are available on the in vivo anthelmintic activity of citronellal (ARAÚJO-FILHO et al., 2018).

The aim of this study was to evaluate the anthelmintic activity of $E$. citriodora essential oil and citronellal, its major constituent, in vivo against sheep gastrointestinal nematodes.

\section{Material and Methods}

This study was approved by the Ethics Committee of the Universidade Estadual do Ceará and registered under the number 2836026/2017.

\section{Eucalyptus citriodora essential oil and citronellal}

E. citriodora essential oil was purchased from Ferquima ${ }^{\circledR}$ (São Paulo, Brazil), and its chemical composition was determined by gas chromatography-mass spectrometry (GC-MS) using a GCMS-QP2010S (Shimadzu ${ }^{\circledR}$, Japan). The following experimental conditions were employed: RTX-5 (30 m x $0.25 \mathrm{~mm}$ ) capillary column; helium carrier gas; injector temperature of $250{ }^{\circ} \mathrm{C}$; detector temperature of $260{ }^{\circ} \mathrm{C}$; column temperature of $50-150{ }^{\circ} \mathrm{C}$ at $2.5^{\circ} \mathrm{C} / \mathrm{min}$ and then $150-250^{\circ} \mathrm{C}$ at $25^{\circ} \mathrm{C} / \mathrm{min}$. The running time was $50 \mathrm{~min}$. For mass spectrometry, the electron impact was $70 \mathrm{eV}$.

The components of E. citriodora oil were identified according to their GC retention time, as expressed by Kovats index, which was calculated using the Van den Dool and Kratz equation (ADAMS, 2007). Additionally, compound mass spectra were compared to spectra from the National Institute for Standard Technology computer database and published spectra. The quantification of the compounds of $E$. citriodora essential oil was performed on the basis of the relative percentage of peak areas of the chromatogram. Citronellal was purchased from Sigma-Aldrich ${ }^{\circledR}$ (product code 27470, $\geq 95 \%$ GC). 


\section{Acute oral toxicity test}

The acute oral toxicity test in mice was performed to define the safe dose of E. citriodora essential oil and citronellal for administration in sheep. Therefore, 14 female Swiss albino mice ( $n=7$ for each group) with an average weight of $26.2 \pm 1.8 \mathrm{~g}$ were allowed to acclimate to the experimental conditions (cycle of $12 \mathrm{~h}$ light/dark and a temperature of $25^{\circ} \mathrm{C}$ ) for seven days, during which they were kept in polypropylene boxes. Commercial feed (Nuvilab ${ }^{\circledR}$, Brazil) and filtered water were provided ad libitum to the rodents.

The acute toxicity test was in accordance with the Organization for Economic Cooperation and Development guideline number 425, the "Up-and-Down" method (OECD, 2008). E. citriodora essential oil and citronellal were administered orally in a single dose progression $(175 ; 440 ; 1,100 ; 2,800$ and 5,000 mg/kg). Each animal was carefully evaluated for up to $48 \mathrm{~h}$ prior to deciding the dose to be given to the next animal. Dose values and estimation of the lethal dose to $50 \%$ (LD50) of animals were obtained using the AOT425StatPgm software (OECD, 2008).

\section{Adult Worm Motility Test (AWMT)}

AWMT was performed based on the methodology described by Hounzangbe-Adote et al. (2005). Briefly, adult $H$. contortus were collected from a sheep naturally infected with gastrointestinal nematodes at eggs per gram of feces (epg) greater than 15,000. Immediately after euthanasia, the abomasum was removed, opened and placed in saline solution at $37^{\circ} \mathrm{C}$. Females of $H$. contortus were rapidly collected and placed into 24 -well plates at a ratio of 3 worms per well in $1 \mathrm{ml}$ of phosphate-buffered saline (PBS) enriched with $4 \%$ penicillin/streptomycin (Sigma-Aldrich ${ }^{\circledR}$ ) at $37^{\circ} \mathrm{C}$. After 1 hour of incubation $\left(37^{\circ} \mathrm{C}, 5 \%\right.$ carbon dioxide), $1 \mathrm{ml}$ of $E$. citriodora essential oil or citronellal at $2,1.75,1.5,1.25,1$ or $0.75 \mathrm{mg} / \mathrm{mL}$ was added to the wells. PBS with $4 \%$ penicillin/streptomycin and $3 \%$ Tween $^{\circledR} 80$ and $100 \mu \mathrm{g} / \mathrm{mL}$ ivermectin were used as negative and positive controls, respectively. After 3, 6 and $12 \mathrm{~h}$ of incubation, the motility of adult worms was observed under an inverted microscope. Eight replicates were performed for each treatment and for each control.

\section{Transmission Electron Microscopy (TEM)}

H. contortus specimens from AWMT were fixed in $2.5 \%$ glutaraldehyde, $4 \%$ paraformaldehyde and $0.1 \mathrm{M} \mathrm{pH} 7.1$ sodium cacodylate buffer for $48 \mathrm{~h}$. The samples were then washed in sodium cacodylate buffer, post fixed in $1 \%$ osmium tetroxide for $1 \mathrm{~h}$ and washed again in the same buffer. The samples were dehydrated in an increasing series of acetone (30, 40, 50, 70, 90 and 100\%) and embedded in Spurr polymerized resin in an oven at $60^{\circ} \mathrm{C}$. Ultrathin slices of $70 \mathrm{~nm}$ were obtained and collected in 400 mesh copper grids and contrasted with 1\% uranyl acetate and 5\% lead citrate. The visualization was performed using a JEOL 1400 PLUS transmission electron microscope at $60 \mathrm{kV}$. The methodology was adapted from Sant'Anna et al. (2013).

\section{Fecal Egg Count Reduction Test (FECRT)}

Sixty sheep from 7 to 16 months old and with an average weight of $24 \pm 5.3 \mathrm{~kg}$ naturally infected with gastrointestinal nematodes with epg greater than 1,000 were selected and randomly divided ( $\mathrm{n}=15)$ into four groups: $\mathrm{G} 1,500 \mathrm{mg} / \mathrm{kg}$ E. citriodora essential oil; G2, $250 \mathrm{mg} / \mathrm{kg}$ citronellal; G3, $2.5 \mathrm{mg} / \mathrm{kg}$ monepantel (Zolvix ${ }^{\circledR}$, Novartis Animal Health, New Zealand); and G4, distilled water (COLES et al., 1992). The treatments were administered orally in a single dose. Fecal samples were collected on days 0,7 and 14 post treatment to estimate epg reduction. Larval culture using a pool of feces from each group was performed to identify nematode genera. The identification of third stage larvae (L3) was based on Ueno \& Gonçalves (1998).

\section{Statistical analysis}

The AWMT experimental design was a factorial arrangement with time (3; 6 and $12 \mathrm{~h}$ ) and treatments (E. citriodora essential oil; citronellal; ivermectin and PBS) as the factors capable of causing worm motility inhibition, calculated as the number of motionless worms/total number of worms per well $\times 100$. Then, we performed a two-way ANOVA followed by comparison with the Bonferroni test to detect significant differences $(P<0.05)$ using GraphPad Prism 5.0. The results were expressed as the mean \pm standard deviation (SD) $(P<0.05)$. The effective concentration to inhibit 50\% (EC50) of worm motility was determined by probit regression using the SPSS 17.0 program.

The FECRT experimental design was a factorial arrangement with time $(0 ; 7$ and 14 days post treatment) and treatments (E. citriodora essential oil; citronellal; monepantel and distilled water) as the factors capable of causing epg variation. The anthelmintic efficacy of $E$. citriodora essential oil and citronellal was interpreted by the FECRT based on each group arithmetic mean fecal egg count using the following formula: FECRT $=100 \times(1-[\mathrm{T} 2 / \mathrm{T} 1]$ [C1/C2] $)$, in which the arithmetic fecal egg count means in controls $(\mathrm{C})$ and treated (T) animals before (T1 and $\mathrm{C} 1$ ) and 7 or 14 days after (T2 and C2) deworming were compared (DASH et al., 1988), using BootStreat 1.0 software (CABARET, 2014). The epg was $\log$-transformed $(\log 10[\mathrm{x}+1])$, submitted to ANOVA and compared using Tukey's test using GraphPad Prism ${ }^{\circledR} 5.0$ software $(P<0.05)$.

Prior to ANOVA, AWMT and FECRT data were submitted to the Shapiro-Wilk test for normality analysis $(P>0.05)$.

\section{Results}

The chemical composition of E. citriodora essential oil is shown in Table 1. Citronellal was confirmed as the essential oil major constituent (63.9\%). The presence of other constituents, including neo-isopulegol $(8.2 \%)$, citronellol $(5.2 \%)$ and iso-isopulegol (4.7\%), was also revealed.

The effects of E. citriodora essential oil and citronellal on $H$. contortus motility inhibition are presented in Table 2 . In the AWMT, the interactions between factors (treatments and times) were statistically significant, except for essential oil at $12 \mathrm{~h}(\mathrm{~F}=2.055$; $\mathrm{P}=0.09)$, essential oil at $1.75 \mathrm{mg}$ in all times $(\mathrm{F}=1.815 ; \mathrm{P}=0.1875)$, 
Table 1. Composition of Eucalyptus citriodora essential oil as determined by gas chromatography-mass spectrometry (GC-MS).

\begin{tabular}{lccc}
\hline \multicolumn{1}{c}{ Constituents } & KI $_{\text {lit }}$ & KI $_{\text {exp }}$ & Percentage (\%) \\
\hline Alpha-pinene & 942 & 940 & 0.46 \\
Beta-pinene & 981 & 980 & 0.87 \\
Limonene & 1030 & 1029 & 0.34 \\
Eucalyptol & 1033 & 1032 & 1.67 \\
Bergamal & 1052 & 1053 & 0.30 \\
Linalool & 1098 & 1099 & 0.34 \\
Rose Oxide & 1109 & 1111 & 0.27 \\
Neo-isopulegol & 1147 & 1149 & $\mathbf{8 . 2 3}$ \\
Citronellal & 1154 & 1157 & $\mathbf{6 3 . 9 4}$ \\
Iso-isopulegol & 1159 & 1162 & $\mathbf{4 . 7 2}$ \\
Neoiso-isopulegol & 1170 & 1173 & 0.39 \\
Citronellol & 1224 & 1228 & $\mathbf{5 . 2 4}$ \\
Menthol<8-hydroxy-neo> & 1327 & 1333 & 0.59 \\
CytronellylAcetate & 1339 & 1346 & 3.27 \\
Beta-caryophyllene & 1408 & 1417 & 0.63 \\
Total identified & - & - & 91.26 \\
\hline
\end{tabular}

$\mathrm{KI}_{\mathrm{lit}}$ : Kovats index found in the literature; $\mathrm{KI}_{\text {exp }}$ : Kovats index for the experiment. The values in bold highlight the chemical constituents found in higher percentages in the essential oil.

Table 2. Mean efficacy (percentage \pm standard deviation) of Eucalyptus citriodora essential oil and citronellal on motility inhibition of Haemonchus contortus.

\begin{tabular}{|c|c|c|c|c|c|c|}
\hline \multirow{3}{*}{ Concentrations } & \multicolumn{3}{|c|}{ E. citriodora essential oil } & \multicolumn{3}{|c|}{ Citronellal } \\
\hline & \multicolumn{3}{|c|}{ Exposure time (hours) } & \multicolumn{3}{|c|}{ Exposure time (hours) } \\
\hline & $3 \mathrm{~h}$ & $6 \mathrm{~h}$ & $12 \mathrm{~h}$ & $3 \mathrm{~h}$ & $6 \mathrm{~h}$ & $12 \mathrm{~h}$ \\
\hline $2 \mathrm{mg} / \mathrm{ml}$ & $100.00 \pm 0.00^{\mathrm{Aa}}$ & $100.00 \pm 0.00^{\mathrm{Aa}}$ & $100.00 \pm 0.00^{\mathrm{Aa}}$ & $91.67 \pm 15.43^{\mathrm{Aa}}$ & $100.00 \pm 0.00^{\mathrm{Aa}}$ & $100.00 \pm 0.00^{\mathrm{Aa}}$ \\
\hline $1.75 \mathrm{mg} / \mathrm{ml}$ & $87.50 \pm 17.26^{\mathrm{Aa}}$ & $91.67 \pm 15.43^{\mathrm{ABa}}$ & $100.00 \pm 0.00^{\mathrm{Aa}}$ & $87.50 \pm 17.26^{\mathrm{Aa}}$ & $95.83 \pm 11.79^{\mathrm{Aa}}$ & $100.00 \pm 0.00^{\mathrm{Aa}}$ \\
\hline $1.5 \mathrm{mg} / \mathrm{ml}$ & $62.49 \pm 11.78^{\mathrm{Ba}}$ & $79.16 \pm 17.26^{\mathrm{Bab}}$ & $95.83 \pm 11.79^{\mathrm{ABb}}$ & $54.16 \pm 17.25^{\mathrm{Ba}}$ & $83.33 \pm 17.82^{\mathrm{ABb}}$ & $95.83 \pm 11.79^{\mathrm{Ab}}$ \\
\hline $1.25 \mathrm{mg} / \mathrm{ml}$ & $45.83 \pm 17.25^{\mathrm{BCa}}$ & $75.00 \pm 15.43^{\mathrm{Bb}}$ & $91.67 \pm 15.43^{\mathrm{ABC}}$ & $41.66 \pm 15.43^{\mathrm{BCa}}$ & $70.83 \pm 21.36^{\mathrm{BCb}}$ & $95.83 \pm 11.79^{\mathrm{Ac}}$ \\
\hline $1 \mathrm{mg} / \mathrm{ml}$ & $45.83 \pm 17.25^{\mathrm{BCa}}$ & $62.50 \pm 21.36^{\mathrm{Ba}}$ & $91.67 \pm 15.43^{\mathrm{ABb}}$ & $37.50 \pm 11.78^{\mathrm{Ca}}$ & $54.16 \pm 17.25^{\mathrm{Ca}}$ & $83.33 \pm 17.82^{\mathrm{ABb}}$ \\
\hline $0.75 \mathrm{mg} / \mathrm{ml}$ & $29.16 \pm 11.78 \mathrm{Ca}$ & $41.66 \pm 15.43^{\mathrm{Ca}}$ & $83.33 \pm 17.82^{\mathrm{Bb}}$ & $20.83 \pm 17.25^{\mathrm{Ca}}$ & $37.50 \pm 11.78^{\mathrm{Da}}$ & $66.66 \pm 25.20^{\mathrm{Bab}}$ \\
\hline $\begin{array}{l}\text { Ivermectin } \\
(0.10 \mathrm{mg} / \mathrm{ml})\end{array}$ & $95.83 \pm 11.79^{\mathrm{Aa}}$ & $100.00 \pm 0.00^{\mathrm{Aa}}$ & $100.00 \pm 0.00^{A a}$ & $95.83 \pm 11.79^{\mathrm{Aa}}$ & $100.00 \pm 0.00^{A a}$ & $100.00 \pm 0.00^{\mathrm{Aa}}$ \\
\hline $\mathrm{PBS}+\mathrm{TW}$ & $0.00 \pm 0.00^{\mathrm{Da}}$ & $8.33 \pm 15.43^{\mathrm{Dab}}$ & $20.83 \pm 17.25^{\mathrm{Cb}}$ & $0.00 \pm 0.00^{\mathrm{Da}}$ & $8.33 \pm 15.43^{\mathrm{Eab}}$ & $20.83 \pm 17.25^{\mathrm{Cb}}$ \\
\hline
\end{tabular}

Capital letters compare means in the columns and small letters compare means in the rows. Different letters indicate significantly different values $(P<0.05)$.

citronellal at $2 \mathrm{mg}$ in all times $(\mathrm{F}=2.333 ; \mathrm{P}=0.1216)$, citronellal at $1.75 \mathrm{mg}$ in all times $(\mathrm{F}=2.227 ; \mathrm{P}=0.1327)$ and ivermectin in all times $(\mathrm{F}=1 ; \mathrm{P}=0.3847)$. The highest concentration of both treatments $(2 \mathrm{mg} / \mathrm{mL})$ completely inhibited the motility of $H$. contortus at 6 and $12 \mathrm{~h}$ post exposure. The lowest concentration of essential oil and citronellal $(0.75 \mathrm{mg} / \mathrm{mL})$ demonstrated 41.66 and $37.50 \%$ (at $6 \mathrm{~h}$ post exposure) and 83.33 and $66.66 \%$ (at $12 \mathrm{~h}$ post exposure) of efficacy on motility inhibition of $H$. contortus, respectively. No statistically significant differences were observed between the positive control and the $2 \mathrm{mg} / \mathrm{mL}$ and $1.75 \mathrm{mg} / \mathrm{mL}$ concentrations for both treatments $(P>0.05)$. The effects on $H$. contortus motility were dose-dependent and greater at $12 \mathrm{~h}$ post exposure. The EC50s of the essential oil and citronellal at $12 \mathrm{~h}$ post exposure were $0.41 \mathrm{mg} / \mathrm{mL}\left(\mathrm{y}=1.28+2.29 * x ; \mathrm{R}^{2}=0.905\right)$ and $0.64 \mathrm{mg} / \mathrm{mL}\left(\mathrm{y}=1.04+4.73^{*} \mathrm{x} ; \mathrm{R}^{2}=0.934\right)$, respectively.
The adult $H$. contortus exposed to E. citriodora essential oil and citronellal exhibited internal ultrastructural modifications (Figure 1). Contact with citronellal induced internal damage, with formation of vacuoles and tissue disorganization. Nematodes exposed to E. citriodora essential oil showed high disorganization in the muscle layer with degradation of the muscular fibrils and vacuole formation.

In the acute toxicity test, four mice died, three from the citronellal group and one animal from the E. citriodora essential oil group. These animals received the highest dose $(5,000 \mathrm{mg} / \mathrm{kg})$. The estimated LD50 values for $E$. citriodora essential oil and citronellal were $5,000 \mathrm{mg} / \mathrm{kg}$ and $2,609 \mathrm{mg} / \mathrm{kg}$, respectively.

The FECRT results are presented in Table 3. In the FECRT, statistical differences between factors (treatments and times) were observed, except for citronellal at 0,7 and 14 days $(F=0.028$; $\mathrm{P}=0.9719)$ and distilled water at 0,7 and 14 days $(\mathrm{F}=0.4926$; 


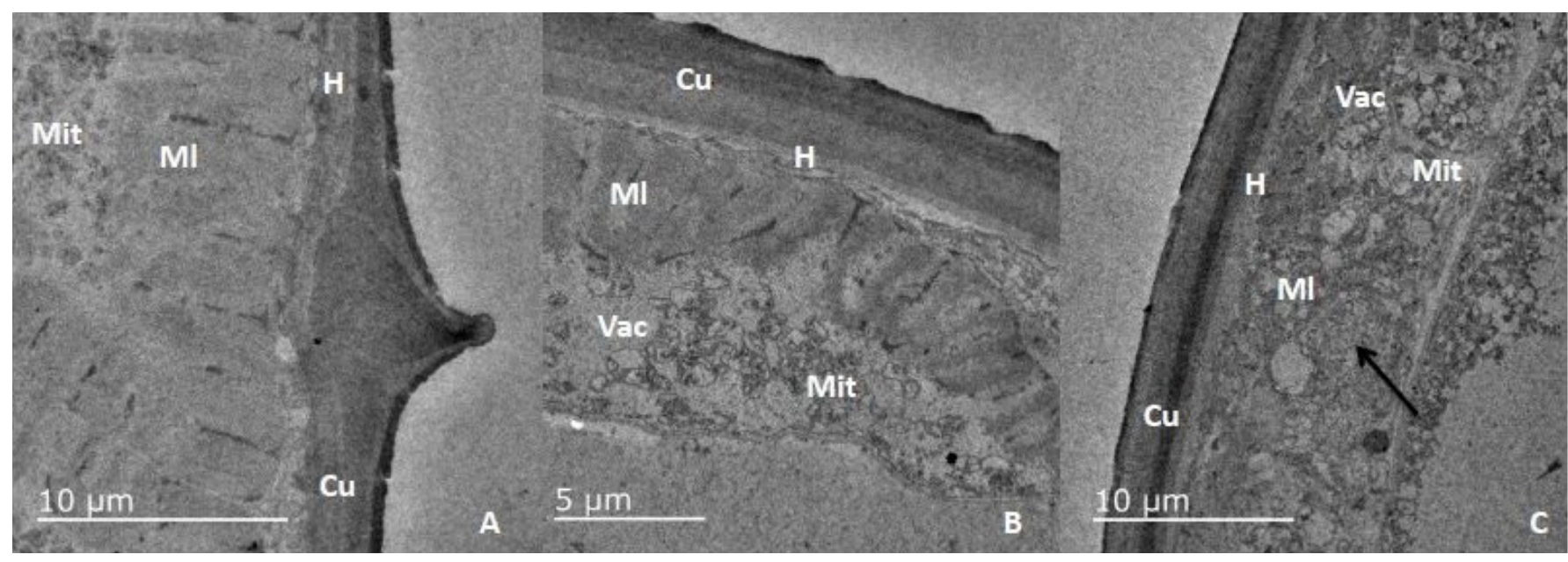

Figure 1. Transmission electron microscopy images of adult Haemonchus contortus after incubation in either PBS + Tween 80 (A), citronellal (B) or Eucalyptus citriodora essential oil. The following structures are shown: cuticle (Cu), hypodermis $(\mathrm{H})$, muscular layer $(\mathrm{Ml})$, mitochondria (Mit) and vacuole ( $\mathrm{Vac}$ ). Note the vacuole formation and changes in the mitochondrial profile. Marked muscular disorganization is shown (black arrow) after exposure to essential oil. Scale bars: $10 \mu \mathrm{m}$ in A and C, $5 \mu \mathrm{m}$ in B.

Table 3. Eggs per gram of feces (mean EPG \pm standard deviation) and efficacy of Eucalyptus citriodora essential oil and citronellal on fecal egg count reduction test (FECRT).

\begin{tabular}{lccc}
\hline \multicolumn{1}{c}{ Treatments } & Day0 & Day7 & Day 14 \\
\hline E. citriodora & $1,835 \pm 1,104^{\mathrm{Aa}}$ & $1,010 \pm 872.7^{\mathrm{Ab}}$ & $675 \pm 600.3^{\mathrm{Ac}}$ \\
Mean EPG & - & 41.8 & 69.5 \\
Efficacy (\%) & $1,800 \pm 1,442^{\mathrm{Aa}}$ & $1,665 \pm 1,233^{\mathrm{Ba}}$ & $1,755 \pm 1,169^{\mathrm{Ba}}$ \\
Citronellal & - & 2.8 & 0.7 \\
Mean EPG & $1,805 \pm 1,262^{\mathrm{Aa}}$ & $155 \pm 206.1^{\mathrm{Cb}}$ & $105 \pm 140.3^{\mathrm{Cb}}$ \\
Efficacy (\%) & & 90.9 & 95.1 \\
Monepantel (Positive Control) & & \\
Mean EPG & & $1,770 \pm 971.9^{\mathrm{Ba}}$ & \\
Efficacy (\%) & $1,825 \pm 1,068^{\mathrm{Aa}}$ & \\
Distilledwater & Negative Control) & & \\
Mean EPG & & & \\
\hline
\end{tabular}

Capital letters compare means in the columns and small letters compare means in the rows. Different letters indicate significantly different values $(P<0.05)$.

$\mathrm{P}=0.6164)$. E. citriodora essential oil and citronellal reduced epg by $69.5 \%$ and $0.7 \%$, respectively, at day 14 post treatment. The epg reduction in the monepantel group $(95.1 \%)$ was significantly higher than those of essential oil and citronellal $(P<0.05)$. There were no statistically significant differences in epg between the citronellal group and the negative control group at days 7 and 14 post treatment $(P>0.05)$.

The larvae recovered by fecal cultures of sheep before treatment were identified as Haemonchus spp. (73\%), Trichostrongylus spp. (23\%), Oesophagostomum spp. (2\%) and Strongyloides spp. (2\%). The larvae recovered 14 days after treatment with $E$. citriodora essential oil were Haemonchus spp. (71\%), Trichostrongylus spp. (25\%), Oesophagostomum spp. (3\%) and Strongyloides spp. (1\%) while those recovered after treatment with citronellal were Haemonchus spp. (69\%), Trichostrongylus spp. (27\%) and Oesophagostomum spp. (4\%). The group that received monepantel showed Haemonchus spp. (56\%), Trichostrongylus spp. (33\%) and Oesophagostomum spp. (11\%).

\section{Discussion}

Natural products derived from plants have been suggested as promising alternatives to be used in the control of gastrointestinal nematodes of small ruminants. The use of phytotherapics with anthelmintic activity would reduce the use of synthetic (such as thiabendazole and levamisole) and semisynthetic (such as ivermectin and derquantel) anthelmintics and consequently delay the development and dissemination of anthelmintic resistance (KEARNEY et al., 2016; LOPES et al., 2018).

Since the geographic origin of the nematodes, as well as the anthelminthic resistance pattern, are indicated as factors that cause variation in the anthelmintic activity of natural products, we chose to use a regional isolate obtained from a farm of the municipality of Caucaia, Ceará, Northeast Brazil, in this work, therefore representing the reality for breeders of small ruminants (CHAN-PÉREZ et al., 2016; GAÍNZA et al., 2016). 
In AWMT, citronellal and essential oil had similar adulticidal effects $(P>0.05)$, completely inhibiting the motility of $H$. contortus in the highest concentrations tested $(2 \mathrm{mg} / \mathrm{kg}$ and $1.75 \mathrm{mg} / \mathrm{kg})$. These results corroborate the hypothesis that the biological properties of the essential oil may be due to its major compounds (BAKKALI et al., 2008). Additionally, these results corroborate those of Araújo-Filho et al. (2018), who used $H$. contortus isolates that were susceptible (Inbred-Susceptible Edinburgh) and multiresistant (Kokstad) to synthetic anthelmintics, and both isolates were sensitive to natural products.

The essential oil of Thymus vulgaris and its major constituent, thymol, demonstrated in vitro efficacy against $H$. contortus eggs, larvae and adults. In the AWMT, T. vulgaris essential oil $(50 \mathrm{mg} / \mathrm{mL})$ and thymol $(25 \mathrm{mg} / \mathrm{mL})$ completely inhibited the $H$. contortus motility within $8 \mathrm{~h}$ post exposure (FERREIRA et al., 2016). In the present study, statistical differences were not observed in the efficacy of $E$. citriodora essential and citronellal at the concentration of $2 \mathrm{mg} / \mathrm{mL}$ on the adult motility. Ferreira et al. (2016) demonstrated that the lowest concentration of thymol $(0.25 \mathrm{mg} / \mathrm{mL})$ showed $91 \%$ of efficacy on motility inhibition of $H$. contortus ( $8 \mathrm{~h}$ post exposure). In the present study, the citronellal at the concentration of $0.75 \mathrm{mg} / \mathrm{mL}$ presented $66.66 \%$ of efficacy on motility inhibition of this nematode ( $12 \mathrm{~h}$ post exposure).

The images of $H$. contortus exposed to citronellal and essential oil demonstrated ultrastructural alterations, such as the disorganization of the muscular layer, formation of vacuoles and alteration in the mitochondrial profile. These changes observed by transmission electron microscopy demonstrate the loss of homeostasis of the parasites exposed to the treatments and can explain the loss of motility, such as the destruction of the muscular layer after exposure to E. citriodora essential oil (BRUNET et al., 2011).

The anthelmintic activity of the essential oil could be attributed to its main compound. Therefore, the isolated major constituent should be more effective than the essential oil at the same concentration (BAKKALI et al., 2008). However, as observed in the in vitro tests the efficacy between $E$. citriodora essential oil and citronellal demonstrated no statistical difference. Thus, the other constituents in the essential oil composition (34.1\%) did not promote significant variation in the in vitro anthelmintic activity of citronellal.

The citronellal was found to be nearly twice as toxic as the E. citriodora essential oil, as demonstrated by their LD50 values of $2,609 \mathrm{mg} / \mathrm{kg}$ and $5,000 \mathrm{mg} / \mathrm{kg}$, respectively. Both substances are considered slightly toxic agents because they have LD50 values of $1,000 \mathrm{mg} / \mathrm{kg}$ to $5,000 \mathrm{mg} / \mathrm{kg}$ (NIESINK et al., 1996).

E. citriodora essential oil promoted reductions of $41.8 \%$ and $69.5 \%$ of epg in sheep at 7 and 14 days post treatment, respectively. These results differ from those of Ribeiro et al. (2014), who achieved $55.9 \%$ epg reduction in sheep at 10 days post treatment with E. citriodora essential oil at $250 \mathrm{mg} / \mathrm{kg}$. The composition of the oil used by Ribeiro et al. (2014) was slightly different from that used in this study for citronellal (67.5\%) and citronellol (6.9\%) contents. On the other hand, the menthol content $(6.1 \%)$ in their oil was more than 10 -fold ours (0.59\%). This monoterpenoid was recently shown to be a positive allosteric modulator of Oesophagostomum dentatum levamisole-sensitive nicotinic acetylcholine receptor. Thus, its use is suggested in combination with cholinomimetic drugs to increase anthelmintic effectiveness (CHOUDHARY et al., 2019).

Goats treated with $500 \mathrm{mg} / \mathrm{kg}$ of $E$. citriodora essential oil for three consecutive days showed reduced epg by $66.2 \%$ and $60.3 \%$ on day 8 and 15 post treatment, respectively (MACEDO et al., 2011). Pharmacokinetics studies for synthetic anthelmintics have shown that goats have greater metabolization capacity than sheep, resulting in low bioavailability and, therefore, less efficacy than in sheep at the same dose, which explains the need for an increase in the number of treatments (LESPINE et al., 2012; SINGH et al., 2018).

In the present study, sheep harboring gastrointestinal nematodes were treated with citronellal $(250 \mathrm{mg} / \mathrm{kg})$ and E. citriodora essential oil $(500 \mathrm{mg} / \mathrm{kg})$. The choice of different doses was made considering previous studies (RIBEIRO et al., 2014) and the percentage of citronellal present in the oil (63.9\%). Curiously, citronellal showed no anthelmintic activity in vivo, causing only a $0.7 \%$ epg reduction. Therefore, as occurred in other studies evaluating natural products derived from plants, in vitro anthelmintic efficacy was not reproduced in vivo (EGUALE et al., 2007; KATIKI et al., 2017).

Citronellal is described as a compound of unstable nature, being subject to reduction reactions for citronellol through the action of isolated enzymes and microorganisms, as well as oxidation reactions generating citronellic acid. It appears that isolated citronellal is more vulnerable to these reactions than citronellal in association with the other constituents that form the essential oil E. citriodora, and perhaps the ruminal microbiota influences this bioconversion. Therefore, pharmacokinetic studies would be important to allow a better understanding of the results of this test (ODA et al., 1996; LENARDÃO et al., 2007; COBELLIS et al., 2016).

The L3 from coprocultures of the animals submitted to FECRT demonstrated a high frequency of Haemonchus spp. (59\% - 79\%) and Trichostrongylus spp. (17\% - 34\%), corroborating the results of other authors whose experiments were carried out in northeast Brazil (ANDRÉ et al., 2016; RIBEIRO et al., 2017). H. contortus is a parasite well stablished under tropical and temperate conditions. In addition the daily egg output $(5,000-15,000)$ and the nematode life cycle ensure the contamination of the pasture and then reinfection of the grazing animals (EMERY et al., 2016). No significant difference of the nematode genera found before and after treatment with the E. citriodora essential oil was observed. Considering that the essential oil promoted the reduction of $69.5 \%$ of epg, it probable affects similarly the nematodes found in abomasum, small intestine and large intestine. Camurça-Vasconcelos et al. (2008) demonstrated that the Lippia sidoides essential oil reduced epg of sheep naturally infected with the genera Haemonchus and Trichostrongylus. Therefore, the efficacy of essential oils against different nematodes genera have been documented.

\section{Conclusion}

E. citriodora essential oil and citronellal inhibited motility and induced ultrastructural damage to adult $H$. contortus in vitro. However, only the essential oil was effective in reducing epg in sheep harboring gastrointestinal nematodes. Therefore, the essential oil would be a better candidate to be included as an 
alternative method for nematode control. In addition, further studies assessing the interactions between essential oil constituents and their pharmacokinetic profiles may help in understanding the anthelmintic activity of natural products.

\section{Acknowledgements}

The authors would like to thank the Conselho Nacional de DesenvolvimentoCientífico e Tecnológico (CNPq) (458011/2014-2) for their financial support. Mr. Araújo-Filho has received a master research scholarship from Coordenação de Pessoal de Nível Superior (CAPES). Dr. Bevilaqua has a researcher fellowship from CNPq (303018/2013-5). The authors would like to thank Beatriz Ferreira for technical help. The structural analyses were made possible through the use of the JEOL 1400 PLUS TEM multiuser equipment facility (FAPERJ grant number E-26/110.040/2013).

\section{References}

Adams RP. Identification of essential oil components by gas chromatography/ quadrupole mass spectroscopy. 4th ed. Illinois: Allured; 2007.

André WPP, Ribeiro WLC, Cavalcante GS, Santos JML, Macedo ITF, Paula HCB, et al. Comparative efficacy and toxic effects of carvacryl acetate and carvacrol on sheep gastrointestinal nematodes and mice. Vet Parasitol 2016; 218: 52-58. http://dx.doi.org/10.1016/j.vetpar.2016.01.001. PMid:26872928.

Araújo-Filho JV, Ribeiro WLC, André WPP, Cavalcante GS, Guerra MCM, Muniz CR, et al. Effects of Eucalyptus citriodora essential oil and its major component, citronellal, on Haemonchus contortus isolates susceptible and resistant to synthetic anthelmintics. Ind Crops Prod 2018; 124: 294-299. http://dx.doi.org/10.1016/j.indcrop.2018.07.059.

Ashraf S, Prichard RK. Haemonchus contortus microtubules are cold resistant. Mol Biochem Parasitol 2014; 193(1): 20-22. http://dx.doi. org/10.1016/j.molbiopara.2014.01.006. PMid:24525483.

Bakkali F, Averbeck S, Averbeck D, Idaomar M. Biological effects of essential oils - a review. Food Chem Toxicol 2008; 46(2): 446-475. http:// dx.doi.org/10.1016/j.fct.2007.09.106. PMid:17996351.

Ballhorn DJ, Kautz S, Heil M, Hegeman AD. Cyanogenesis of wild lima bean (Phaseolus lunatus L.) is an efficient direct defence in nature. PLoS One 2009; 4(5): 1-7. http://dx.doi.org/10.1371/journal.pone.0005450. PMid:19424497.

Batish DR, Singh HP, Kohli RK, Kaur S. Eucalyptus essential oil as a natural pesticide. For Ecol Manage 2008; 256(12): 2166-2174. http:// dx.doi.org/10.1016/j.foreco.2008.08.008.

Benelli G, Pavela R. Beyond mosquitoes - Essential oil toxicity and repellency against bloodsucking insects. Ind Crops Prod 2018; 117: 382392. http://dx.doi.org/10.1016/j.indcrop.2018.02.072.

Brito DR, Ootani MA, Ramos ACC, Sertão WC, Aguiar RWS. Efeito dos óleos de citronela, eucalipto e composto citronelal sobre micoflora e desenvolvimento de plantas de milho. J Biotechnol Biodivers 2012; 3(4): 184-192. http://dx.doi.org/10.20873/jbb.uft.cemaf.v3n4.brito.

Brunet S, Fourquaux I, Hoste H. Ultrastructural changes in the thirdstage, infective larvae of ruminant nematodes treated with sainfoin (Onobrychis viciifolia) extract. Parasitol Int 2011; 60(4): 419-424. http:// dx.doi.org/10.1016/j.parint.2010.09.011. PMid:21787880.
Cabaret J. Reliable phenotypic evaluations of anthelmintic resistance in herbivores: how and when should they be done? In: Quick W. Anthelmintics: clinical pharmacology uses in veterinary medicine and efficacy. New York: Nova Science Publisher; 2014. p. 1-26.

Camurça-Vasconcelos ALF, Bevilaqua CML, Morais SM, Maciel MV, Costa CTC, Macedo ITF, et al. Anthelmintic activity of Lippia sidoides essential oil on sheep gastrointestinal nematodes. Vet Parasitol 2008; 154(1-2): 167-170. http://dx.doi.org/10.1016/j.vetpar.2008.02.023. PMid:18423877.

Chan-Pérez JI, Torres-Acosta JFJ, Sandoval-Castro CA, Hoste H, Castañeda-Ramírez GS, Vilarem G, et al. In vitro susceptibility of ten Haemonchus contortus isolates from different geographical origins towards acetone:water extracts of two tannin rich plants. Vet Parasitol 2016; 217 53-60. http://dx.doi.org/10.1016/j.vetpar.2015.11.001. PMid:26827861.

Choudhary S, Marjianovic DS, Wong CR, Zhang X, Abongwa M, Coats JR, et al. Menthol acts as a positive allosteric modulator on nematode levamisole sensitive nicotinic acetylcholine receptors. Int J Parasitol Drugs Drug Resist 2019; 9: 44-53. http://dx.doi.org/10.1016/j. ijpddr.2018.12.005. PMid:30682641.

Cobellis G, Trabalza-Marinucci M, Yu Z. Critical evaluation of essential oils as rumen modifiers in ruminant nutrition: A review. Sci Total Environ 2016; 545-546: 556-568. http://dx.doi.org/10.1016/j.scitotenv.2015.12.103. PMid:26760275.

Coles GC, Bauer C, Borgsteede FHM, Geerts S, Klei TR, Taylor MA, et al. World association for the Advancement of Veterinary Parasitology (W.A.A.V.P.) methods for detection of anthelmintic resistance in nematodes of veterinary importance. Vet Parasitol 1992; 44(1-2): 35-44. http://dx.doi. org/10.1016/0304-4017(92)90141-U. PMid:1441190.

Dash K, Hall K, Barger IA. The role of arithmetic and geometric worm egg counts in faecal egg count reduction test and in monitoring strategic drenching programs in sheep. Aust Vet J1988; 65(2): 66-68. http://dx.doi. org/10.1111/j.1751-0813.1988.tb07359.x. PMid:3355458.

Eguale T, Tilahun G, Debella A, Feleke A, Makonnen E. In vitro and in vivo anthelmintic activity of crude extracts of Coriandrum sativum against Haemonchus contortus. J Ethnopharmacol 2007; 110(3): 428-433. http:// dx.doi.org/10.1016/j.jep.2006.10.003. PMid:17113738.

Elaissi A, Rouis Z, Mabrouk S, Salah KB, Aouni M, Khouja ML, et al. Correlation between chemical composition and antibacterial activity of essential oils from fifteen Eucalyptus species growing in the Korbous and Jbel Abderrahman arboreta (North East Tunisia). Molecules 2012; 17(3): 3044-3057. http://dx.doi.org/10.3390/molecules 17033044 PMid:22410416.

Emery DL, Hunt PW, Le Jambre LF. Haemonchus contortus: the then and now, and where to from here? Int J Parasitol 2016; 46(12): 755769. http://dx.doi.org/10.1016/j.ijpara.2016.07.001. PMid:27620133.

Ferreira LE, Benincasa BI, Fachin AL, França SC, Contini SSH, Chagas ACS, et al. Thymus vulgaris L. essential oil and its main component thymol: anthelmintic effects against Haemonchus contortus from sheep. Vet Parasitol 2016; 228: 70-76. http://dx.doi.org/10.1016/j.vetpar.2016.08.011. PMid:27692335.

Ferreira LE, Castro PMN, Chagas ACS, França SC, Beleboni RO. In vitro anthelmintic activity of aqueous leaf extract of Annona muricata L. (Annonaceae) against Haemonchus contortus from sheep. Exp Parasitol 2013; 134(3): 327-332. http://dx.doi.org/10.1016/j.exppara.2013.03.032. PMid:23583362.

Gaínza YA, Fantatto RR, Chaves FCM, Bizzo HR, Esteves SN, Chagas ACS. Piper aduncum against Haemonchus contortus isolates: cross resistance 
and the research of natural bioactive compounds. Rev Bras Parasitol Vet 2016; 25(4): 383-393. http://dx.doi.org/10.1590/s1984-29612016073. PMid:27925067.

Gbenou JD, Ahounou JF, Akakpo HB, Laleye A, Yayi E, Gbaguidi F, et al. Phytochemical composition of Cymbopogon citratus and Eucalyptus citriodora essential oils and their anti-inflammatory and analgesic properties on wistar rats. Mol Biol Rep 2013; 40(2): 1127-1134. http://dx.doi.org/10.1007/ s11033-012-2155-1. PMid:23065287.

Hasegawa T, Takano F, Takata T, Niiyama M, Ohta T. Bioactive monoterpene glycosides conjugated with gallic acid from the leaves of Eucalyptus globulus. Phytochemistry 2008; 69(3): 747-753. http://dx.doi. org/10.1016/j.phytochem.2007.08.030. PMid:17936865.

Hounzangbe-Adote MS, Paolini V, Fouraste I, Moutairou K, Hoste H. In vitro effects of four tropical plants on three life-cycle stages of the parasitic nematode, Haemonchus contortus. Res Vet Sci 2005; 78(2): 155160. http://dx.doi.org/10.1016/j.rvsc.2004.05.009. PMid:15563923.

Katiki LM, Gomes ACP, Barbieri AME, Pacheco PA, Rodrigues L, Veríssimo CJ, et al. Terminalia catappa: chemical composition, in vitro and in vivo effects on Haemonchus contortus. Vet Parasitol 2017; 246: 118 123. http://dx.doi.org/10.1016/j.vetpar.2017.09.006. PMid:28969774.

Kearney PE, Murray PJ, Hoy JM, Hohenhaus M, Kotze A. The 'Toolbox' of strategies for managing Haemonchus contortus in goats: what's in and what's out. Vet Parasitol 2016; 220: 93-107. http://dx.doi.org/10.1016/j. vetpar.2016.02.028. PMid:26995728.

Kim JK, Kang CS, Lee JK, Kim YR, Han HY, Yun HK. Evaluation of repellency effect of two natural aroma mosquito repellent compounds, citronella and citronellal. Entomol Res 2005; 35(2): 117-120. http:// dx.doi.org/10.1111/j.1748-5967.2005.tb00146.x.

Kotze A, Prichard R. Anthelmintic resistance in Haemonchus contortus: history, mechanisms and diagnosis. Adv Parasitol 2016; 93: 397-428. http://dx.doi.org/10.1016/bs.apar.2016.02.012. PMid:27238009.

Lenardão EJ, Botteselle GV, Azambuja F, Perin G, Jacob RG. Citronellal as key compound in organic synthesis. Tetrahedron 2007; 63(29): 66716712. http://dx.doi.org/10.1016/j.tet.2007.03.159.

Lespine A, Chartier C, Hoste H, Alvinerie M. Endectocides in goats: pharmacology, efficacy and use conditions in the contex to anthelmintics resistance. Small Rumin Res 2012; 103(1): 10-17. http://dx.doi.org/10.1016/j. smallrumres.2011.10.013.

Lopes LG, Silva MH, Figueiredo A, Canuto KM, Brito ES, Ribeiro PRV, et al. The intake of dry cashew apple fiber reduced fecal egg counts in Haemonchus contortus-infected sheep. Exp Parasitol 2018; 195: 38-43. http://dx.doi.org/10.1016/j.exppara.2018.10.004. PMid:30393118.

Macedo ITF, Bevilaqua CML, Oliveira LMB, Camurça-Vasconcelos ALF, Vieira LS, Amóra SSA. Evaluation of Eucalyptus citriodora essential oil on goat gastrointestinal nematodes. Rev Bras Parasitol Vet 2011; 20(3):
223-227. http://dx.doi.org/10.1590/S1984-29612011000300009. PMid:21961753.

Maciel MV, Morais SM, Bevilaqua CML, Silva RA, Barros RS, Sousa RN, et al. Chemical composition of Eucalyptus spp. essential oils and their insecticidal effects on Lutzomyia longipalpis. Vet Parasitol 2010; 167(1): 1-7. http://dx.doi.org/10.1016/j.vetpar.2009.09.053. PMid:19896276.

Nakahara K, Alzoreky NS, Yoshihashi T, Nguyen HT, Trakoontivakorn G. Chemical composition and antifungal activity of essential oil from Cymbopogon nardus (Citronella Grass). Jpn Agric Res Q 2003; 37(4): 249-252. http://dx.doi.org/10.6090/jarq.37.249.

Niesink RJM, de Vries J, Hollinger MA. Toxicology: principles and practice. Boca Raton: CRC Press; 1996.

Oda S, Inada Y, Kobayashi A, Kato A, Matsudomi N, Ohta H. Coupling of metabolism and bioconversion: microbial esterification of citronellol with acetyl coenzyme a produced via metabolism of glucose in an interface bioreactor. Appl Environ Microbiol 1996; 62(7): 2216-2220. PMid:16535347.

Organisation for Economic Co-operation and Development - OECD. Acute Oral Toxicity: Up-and-Down Procedure (UDP) [online]. Paris: OECD; 2008 (Test Guideline; 425). [cited 2019 Jan 11]. Available from: https://ntp.niehs.nih.gov/iccvam/suppdocs/feddocs/oecd/oecdtg425.pdf

Ribeiro JC, Ribeiro WL, Camurça-Vasconcelos AL, Macedo IT, Santos JM, Paula HC, et al. Efficacy of free and nanoencapsulated Eucalyptus citriodora essential oil on sheep gastrointestinal nematodes and toxicity for mice. Vet Parasitol 2014; 204(3-4): 243-248. http://dx.doi.org/10.1016/j. vetpar.2014.05.026. PMid:24929446.

Ribeiro WLC, André WPP, Cavalcante GS, Araújo-Filho JV, Santos JML, Macedo ITF, et al. Effects of Spigelia anthelmia decoction on sheep gastrointestinal nematodes. Small Rumin Res 2017; 153: 146-152. http:// dx.doi.org/10.1016/j.smallrumres.2017.06.001.

Sales N, Love S. Resistance of Haemonchus sp. to monepantel and reduced efficacy of a derquantel/abamectin combination confirmed in sheep in NSW, Australia. Vet Parasitol 2016; 228: 193-196. http://dx.doi. org/10.1016/j.vetpar.2016.08.016. PMid:27692326.

Sant'anna V, Vommaro RC, de Souza W. Caenorhabditis elegans as a model for the screening of anthelmintic compounds: ultrastructural study of the effects of albendazole. Exp Parasitol 2013; 135(1): 1-8. http://dx.doi. org/10.1016/j.exppara.2013.05.011. PMid:23727123.

Singh P, Scott I, Jacob A, Storillo VM, Pomroy WE. Pharmacokinetics of abamectin in sheep, goat and deer. Small Rumin Res 2018; 165: 30-33. http://dx.doi.org/10.1016/j.smallrumres.2018.06.009.

Ueno H, Gonçalves PC. Manual para diagnóstico das helmintoses de ruminantes. Tokyo: Japan International Cooperation Agency; 1998.

Vitti AMS, Brito JO. Óleo essencial de eucalipto. Documentos Florestais 2003; 17: 1-35. 